\title{
Specifities of Application of Activating Fluxes in Electrical Welding in Protective Atmosphere
}

\author{
Oleksandr M. Savitskyi \\ $\mathrm{PhD}$ \\ E.O.Paton Electric Welding Institute \\ The NAS of Ukraine, Kyiv \\ Ukraine \\ Mychailo M. Savitskyi \\ Professor \\ E.O.Paton Electric Welding Institute \\ The NAS of Ukraine, Kyiv \\ Ukraine \\ Darko Bajić \\ Full Professor \\ University of Montenegro \\ Faculty of Mechanical Engineering \\ Montenegro
}

Without the increase in welding current, activating fluxes for arc welding with a non-consumable electrode (ATIG) and for welding with a consumable electrode (AMIG) allow for the increase in depth of penetration 24 times. These two procedures are essentially different in terms of their implementation. In AMIG welding, the problems in the creation of a welding joint stem from the influence of the critical value of the metal bath surface. The critical value of the surface is achieved by using welding current of 280-300 A and, according to the experimental results, its value is 160-190 $\mathrm{mm}^{2}$. By achieving the critical surface value, the positive influence of the activating fluxes on the penetration ability of the electric arc is lost. Optimum interval of welding current for AMIG is 200-500 A, which significantly exceeds the permissible threshold. In ATIG welding, the effect of the critical surface of the bath is not observed, because it requires welding current that exceeds the optimal value interval (max. 250 A), which is conditioned by the stability of the non-consumable electrode. By increasing welding current over 250-300 A, the working tip of the electrode is rapidly consumed and the stability of the welding process is disturbed.

Keywords: welding, activating flux, penetration depth, metal bath, critical value surface, heat input

\section{INTRODUCTION}

For conventional arc welding process the composition of shielding gas plays an important role ensuring the quality of welds, but has a marginal influence on the depth of arc penetration [1]. The application of activating flux during welding increases the depth of penetration 2-3 times without increasing the heat input of welding [2-8].

There have been earlier attempts to apply activating fluxes in welding with consumable electrodes. However, this did not yield the expected results, although it was possible to achieve a slight increase in penetration. Basically, activation of the electric arc in metal inert gas (MIG) welding was used to improve the transfer of electrode material, to reduce spattering, and to make a quality weld seam [9-12]. At the expense of the reduction in surface stress, droplets of electrode material are smaller and the frequency of their transmission is increased. With the use of filler wires that contained the activators, seam formation improved, which was manifested by a decrease in excess weld metal reinforcement, smoother transition towards the base metal and the absence of undercut [9-12]. These welding wires primarily contained compounds based on the alkali and alkaline earth metals, which contribute to the reduction in the surface tension of a liquid metal. The

Received: Februar 2020, Accepted: May 2020

Correspondence to: Prof. dr Darko Bajić, University of Montenegro, Faculty of Mechanical Engineering,

Dzordza Vashingtona bb, 81000 Podgorica, Montenegro

E-mail: darko@ucg.ac.me

Doi: 10.5937/fme2003576S

(C) Faculty of Mechanical Engineering, Belgrade. All rights reserved task of increasing the penetration was not solved.

At the beginning of the 1990s, positive results were obtained with the use of AMIG welding [13]. Currently, AMIG welding allows the increase in the depth of penetration up to 3-4 times or the reduction of welding heat input up to 6 times, indicating a positive influence on the properties of metals within a welding joint [2, 4-6, 14].

Although there are similarities in the ATIG and AMIG welding processes they are fundamentally different in terms of the pertaining conditions. These conditions include different sensitivity to the presence of impurities in welded material, the difference in the thermal power of the electric arc and the difference in the formation of the metal bath.

\section{EXPERIMENTAL RESULTS AND DISCUSSION}

In steels, regardless of their purity, there are always impurities such as sulfur and oxygen. The percentage content of these impurities determines the degree of purity of the steel. In refined steels their content is minimal and gradually increases in proportion to the reduction of purity of the metal.

Sulfur and oxygen are extremely strong counteragents $[3,15]$, strongly affecting the electric arc penetration ability, which is reflected in the increase in the material penetration depth. This is confirmed by the results of our research, shown in Fig. 1. This histogram enables the assessment of the influence of the degree of steel purity on the depth of penetration of the electric arc in metal inert gas (TIG) welding. If we compare the data, we can see that with welding refined steels we can achieve a minimum penetration depth. When switching 
to quality structural alloy steels with high purity using conventional melting, the depth of penetration increases $\sim 1.5$ times (Fig.1) and is maintained at that level in other structural steels.

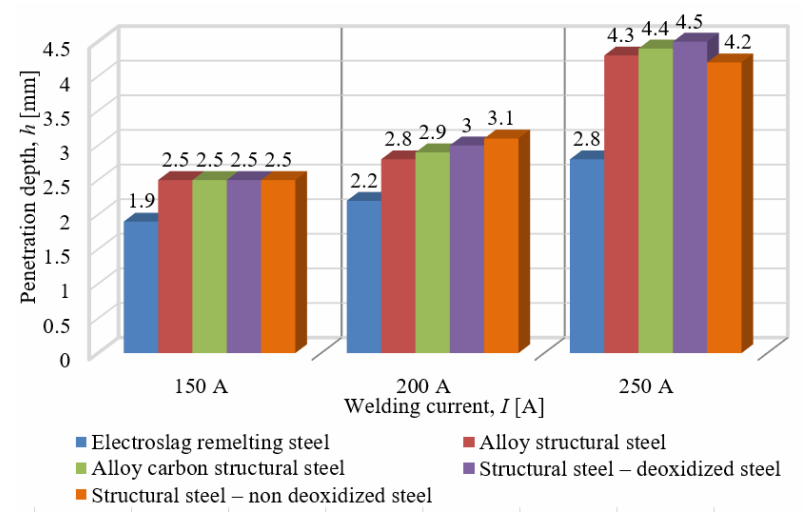

Figure 1. Impact of purity of steel on penetration depth in TIG welding

With MIG welding, the degree of steel purity practically does not affect the depth of penetration (Fig. 2). At all intervals of the welding current, the depth of penetration in steel is approximately equal, and the difference does not exceed the value of $0.2 \mathrm{~mm}$. The explanation is in the fact that all welding wires contain up to $0.025 \%$, and a low carbon welding wire contains up to $0.03 \%$ sulfur [16-15]. Welding wires with elevated and high carbon content, used for welding and surfacing, contain up to $0.035-0.04 \%$ sulfur $[19,20]$. In addition, a sufficient amount of oxygen is always present in the protective atmosphere used in the MIG welding, which explains the absence of a significant influence of steel purity on its depth of penetration. Also, welding wires contain deoxidants which serve as alloying elements [16-18].

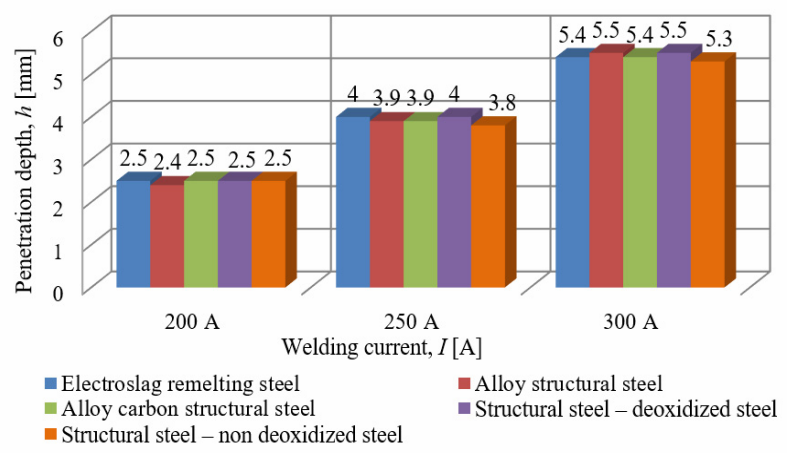

Figure 2. Impact of purity of steel on depth of penetration in MIG welding

Therefore, MIG welding is not sensitive to the presence of admixtures in a welded metal. At the same time, in TIG welding, the presence of admixtures significantly affects the increase in the penetration depth which can be increased up to 1.5 times. It should be taken into account that the arrangement of the admixture in the metal is uneven and this unevenness increases with a decrease in the degree of its purity, which is followed by uneven penetration along the length of the seam. The difference in the depth of penetration in the individual parts of a welding joint may vary up to 1.5 $\mathrm{mm}$. This difference is increased by reducing the purity of steel and the welding current.
The other difference between TIG and MIG welding is a big difference in the energy capacity of these processes. One of the indicators of energy capacity while arc welding is the electric arc heat input [20,21]:

$$
q=I \cdot U \cdot \eta
$$

The results of the research (Fig. 3) show that with the same welding current as with the MIG process, the thermal power of the electric arc is 2-3 times higher than with the TIG process. This is explained by the fact that under these welding conditions, the electric arc voltage of MIG welding is 1.5-2 times higher. In addition, the efficiency coefficient of electric arc in the MIG procedure is 1.2-1.35 times higher than in the TIG welding process $[20,21]$.

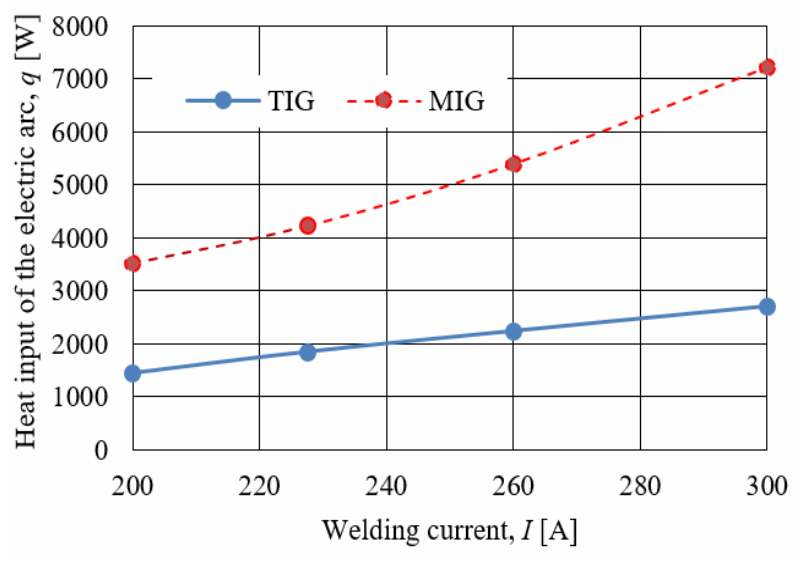

Figure 3. Heat energy of the electric arc

According to our data (Fig. 3), in TIG welding with $200 \mathrm{~A}$, the heat input of the electric arc is $1440 \mathrm{~W}$. With the same welding current, the MIG process produces $3520 \mathrm{~W}$ of heat input of electric arc, which means it is 2.44 times higher. With $300 \mathrm{~A}$ of welding current, this difference is more pronounced and is 2.67 times bigger. Therefore, with the same welding current, the heat input of the electric arc in a MIG process is higher than in the TIG process, and this difference is increased by increasing the welding current.

Another indicator of the energy capacity of the welding process is heat input, which represents the ratio of the heat input of the electric arc $(q)$ and welding speed $\left(v_{w}\right)-q / v_{w}[20,21]$.

In practice, TIG welding is performed at an optimum speed of 6-12 m/h. In extreme cases, the welding speed can be up to $18 \mathrm{~m} / \mathrm{h}$. MIG welding is carried out with an optimum speed of $25-30 \mathrm{~m} / \mathrm{h}$. Not counting the application of activating fluxes, without special technological measures, the TIG procedure cannot achieve faster speeds, as it is the case with the MIG procedure. For the purpose of comparing the heat input under the same welding conditions, it is wise to use the welding speed of 6-12 m/h for MIG welding.

Fig. 4 curves depict the dependence of heat input on welding current for the TIG and MIG welding with a welding speed of $6 \mathrm{~m} / \mathrm{h}$ and $12 \mathrm{~m} / \mathrm{h}$. Data show that with identical welding current, the heat input of MIG with a welding speed of $12 \mathrm{~m} / \mathrm{h}$ significantly exceeds the value of the heat input of TIG welding, regardless of its welding speed. 


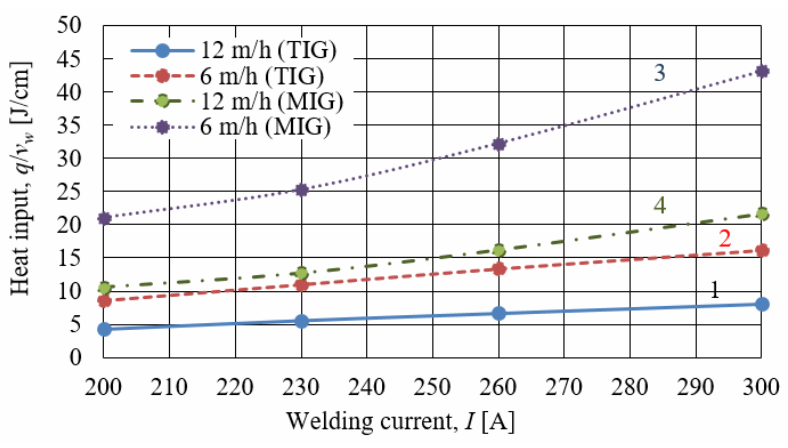

Figure 4. Heat welding input: TIG: curve $1(6 \mathrm{~m} / \mathrm{h})$ and 2 (12 $\mathrm{m} / \mathrm{h})$; MIG: curve $4(6 \mathrm{~m} / \mathrm{h})$ and $4(12 \mathrm{~m} / \mathrm{h})$

It has been experimentally established for TIG welding with heat input corresponding to curves 1 and 2 (Fig. 4), that activating fluxes increase the depth of penetration within the limits of the optimal welding currents. In MIG welding with heat input corresponding to curves 3 and 4 (Fig. 4), the influence of the flux on the depth of penetration is not significant.

Based on numerous experimental data, it has been concluded that when achieving the welding current of 280-300 A, the influence of activating fluxes on the depth of penetration in AMIG welding is terminated. By achieving this level of welding current, the depth of penetration is reduced to the level of the conventional MIG welding (Fig. 5). This is not the case with the ATIG welding process.

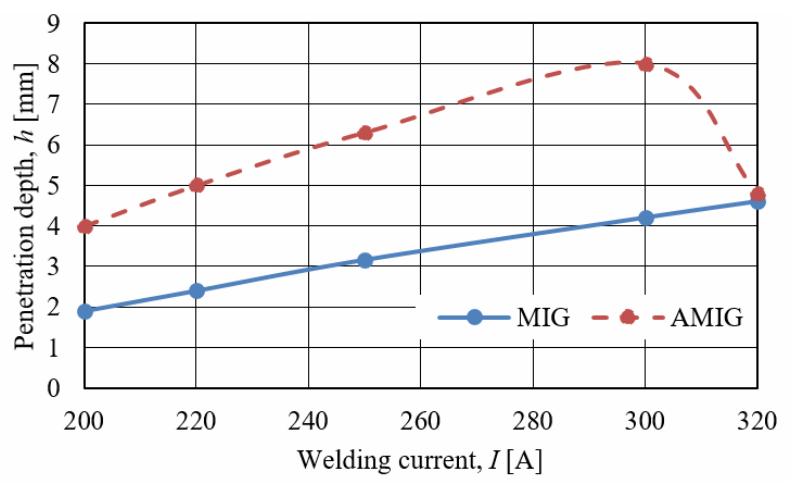

Figure 5. Intensity of the impact of the activating flux on the depth of penetration with MIG welding depending on the welding current

Figure 6 shows curves reflecting the impact of welding current on the surface of the metal bath. By comparing the diagram (Fig. 4 and Fig. 6) it is possible to evaluate the influence of the corresponding welding current and the heat input on the surface of the metal bath in terms of TIG and MIG welding. Obviously, at all intervals of welding current and heat input, the surface of the metal bath for MIG welding is greater than the corresponding surface of TIG welding.

The maximum energy capacity of these arc welding processes is achieved at the welding speed of $6 \mathrm{~m} / \mathrm{h}$ and the minimum at the speed of $12 \mathrm{~m} / \mathrm{h}$. Based on the results of data pairing (Fig. 4 and Fig. 6), it is worthwhile to compare the surfaces of metal baths with the minimum energy capacity of MIG and the maximum energy capacity of TIG welding.

For MIG welding with the current of $200 \mathrm{~A}$ and the welding speed of $12 \mathrm{~m} / \mathrm{h}$, the heat input is $10571 \mathrm{~J} / \mathrm{cm}$.
The maximum energy capacity of TIG welding is achieved by the welding current of $300 \mathrm{~A}$ and the welding speed of $6 \mathrm{~m} / \mathrm{h}$. With these welding parameters, the heat input is $16167 \mathrm{~J} / \mathrm{cm}$, which is 1.53 times more than MIG welding. The metal bath surface is $140 \mathrm{~mm}^{2}, 23.08 \%$ less than for MIG welding with minimum heat input.

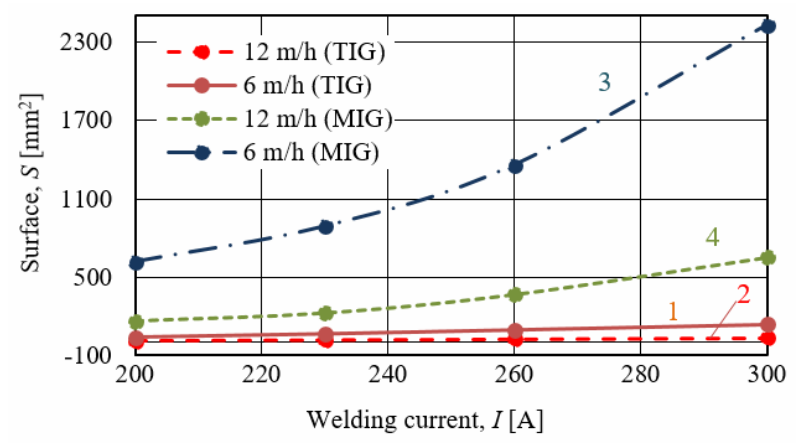

Figure 6. Surface of the metal bath: TIG: curve $1(6 \mathrm{~m} / \mathrm{h})$ and $2(12 \mathrm{~m} / \mathrm{h})$; MIG: curve $3(6 \mathrm{~m} / \mathrm{h})$ and $4(12 \mathrm{~m} / \mathrm{h})$

Under these conditions, the surface of the metal bath with the minimum energy capacity of the MIG welding process exceeds the corresponding indicator of the TIG welding process at the maximum energy capacity. This difference is increased with increasing energy capacity of MIG welding (Fig. 4 and Fig. 6). In addition to the difference in the heat input of welding, this phenomenon is also explained by the difference in the processes of creating a metal bath. If no additional material is used, in TIG welding process metal bath is formed at the expense of melting the base metal. The formation of metal bath for MIG welding is done at the expense of melting the base and electrode metal. With the increase in the energy capacity of the MIG welding process, the amount of additional material that melts and transfers in the metal bath increases. Therefore, the volume, and also the surface of the metal bath at MIG welding, is higher than with the TIG welding.

The results of the investigation point to the conclusion that there is a critical value of the bath surface area, and when this value is exceeded, activating fluxes do not have any influence on the penetration depth. Experiments were performed to determine the critical value of the metal bath surface using the MIG process. According to the experimental results, this surface is $160-190 \mathrm{~mm}^{2}$, and according to the calculation, it is $156-200 \mathrm{~mm}^{2}$. Values are very close. When the critical value of the metal bath surface is reached, activating fluxes react outside the electric arc.

In AMIG welding, the critical value of the metal bath surface is achieved at the welding current of 280$300 \mathrm{~A}$. In ATIG welding, the critical value of the metal bath surface is not completely achieved, because welding is achieved at substantially lower welding current values than is necessary to achieve critical surface values. The optimum value of the welding current for the ATIG process is less than $250 \mathrm{~A}$, which is conditioned by the stability of an insoluble electrode. With the increase in the welding current above 250-300 A, the working tip of the electrode is rapidly consumed and the stability of the electric arc is disturbed and, consequently, of the welding process as a whole. As a comparison, the optimal interval for welding with 
AMIG process is $200-500 \mathrm{~A}$ and in most cases it exceeds the value of 280-300 A, thus achieving the critical surface of the metal bath. This is one of the explanations of the failure of previous attempts to apply activating flux in the MIG welding.

Considering the properties of the TIG and MIG welding, and also the ATIG and AMIG welding, it is possible to significantly reduce or completely eliminate the negative impact of the critical value of the metal bath surface on the effectiveness of AMIG welding.

\section{CONCLUSION}

Regardless of the similarities between the ATIG and the AMIG welding processes, they differ significantly in terms of their implementation: the difference in sensitivity towards the presence of admixtures in the welded material, the difference in the heat input of the electric arc at which welding is achieved and the difference in the conditions of the metal bath formation.

It was found that there is a critical surface of the metal bath where, if this value is exceeded, the activating fluxes do not show any influence on the penetration ability of the electric arc.

The effect of the critical surface of the metal bath is not manifested with the ATIG welding, because the interval of its optimum welding current is significantly lower than the interval in which the metal bath is formed with the critical value of its surface.

\section{REFERENCES}

[1] Britto J.G., Rajan A. J., Murugesan G., Prabhakaran R., Jeevahan J., Mageshwaran G.: Enhancement of Mechanical Properties of Alloy Steel by GTAW with Different Purge/Shielding Gases, FME Transactions, Vol.48, No. 1, pp.149-154, 2020.

[2] Bajic D.R., Savitsky M.M., Melnichuk G.M., Lupan A.F.: A-TIG welding of structural steels for power engineering applications, The Paton Welding Journal, No. 9, pp. 30-34, 2002.

[3] Макара А.М., Савицкий М.М., Кушниренко Б.Н. at al: Влияние рафинирования на проплавление металла при дуговой сварке (The effect of refining on metal penetration in arc welding), Автоматическая сварка (Automatic Welding), No. 9, pp. 7-10, 1977.

[4] Савицкий А.М., Савицкий М.М., Шкрабалюк Ю.Н.: Улучшение технологических и экологических характеристик сварки углеродистых сталей в инертных газах за счет активации дуги (Improving the technological and environmental characteristics of welding carbon steel in inert gases due to arc activation), Проблемы машиностроения (Journal of Mechanical Engineering), No. 5, pp. 58-64, 2011.

[5] Savicky A.M., Bajić D., Savicky M.M. at al: Orbital welding technology of pipeline application of activating flux, Welding and Welded Structures, Vol. 55, No. 3, pp. 83-90, 2010.

[6] Savitskij M.M., Savitskij A.M., Bajić D., Blečić Ž.: MIG welding technology using activating fluxes,
Welding and Welded Structures, Vol. 49, No. 1, pp. 10-14, 2004.

[7] Ramkumar K.D., Varma J.L.N., Chaitanya G., Logesh S. et al: Experimental investigations on the $\mathrm{SiO} 2$ flux-assisted GTA welding of super-austenitic stainless steels, The International Journal of Advanced Manufacturing Technology, No. 93, pp. 129-140, 2017.

[8] Venkatesan G., Muthupandi V., Justine J.: Activated TIG welding of AISI 304L using monoand tri-component fluxes, The International Journal of Advanced Manufacturing Technology, No. 93, pp. 329-336, 2017.

[9] Воропай Н.М., Бельфор Л.М.: Механизированная сварка в $\mathrm{CO} 2$ активированной проволокой диаметром 3...4 мм (Mechanized welding in $\mathrm{CO} 2$ by activated wire with a diameter of 3 ... $4 \mathrm{~mm}$ ), Автоматическая сварка (Automatic Welding), No. 10, pp. 51-54, 1981.

[10] Воропай Н.М., Костенюк Н.И.: Влияние состава активированной проволоки на характеристики процесса сварки в углекислом газе (The influence of the composition of the activated wire on the characteristics of the welding process in carbon dioxide), Автоматическая сварка (Automatic Welding), No. 7, pp. 2-5, 1986.

[11] Воропай Н.М.: Особенности и технологические возможности процесса сварки в защитных газах активированным плавящимся электродом (Features and technological capabilities of the process of welding in shielding gases by an activated consumable electrode), Сварочное производство (Svarochnoe Proizvodstvo), No. 4, pp. 13-19, 1994.

[12]Патон Б.Е., Воропай Н.М.: Сварка активированным плавящимся электродом в защитном газе (Welding by activating soluble electrode in shielding gas), Автоматическая сварка (Automatic Welding), No. 1, pp. 1-6, 1979.

[13] Dydko D.A., Savitskii A.M., Savitskii M.M.: Consumable electrode welding in shielding gases using an activating flux, The Paton Welding Journal, No. 10, pp. 599-601, 1996.

[14] Savytsky A.M., Savytsky M.M., Bajić D.: MIG /MAG welding with activation flux, Proceedings counseling welding of the $29^{\text {th }}$ Conference with International Participation WELDING 2016, 1417. 09. 2016, Srebrno jezero, pp. 82-91, Paper II.1.

[15] Savytsky O., Savytsky M., Bajic D., Shkrabalyuk Y.: Influece of the impurities on the depth of penetration with carbon steel welding, Metalurgija, Vol. 53, No. 2, pp. 167-170, 2014.

[16] Акулов А.И., Бельчук Г.А., Демянцевич В.П.: Технология и оборудование сварки плавлением (Technology and equipment for fusion welding), М.: Машиностроение, Moskva, 1977.

[17]Патон Б.Е.: Технология электрической сварки плавлением (Technology of electric fusion welding), М.: Машиностроение, Moskva, 1974.

[18] Фрумин И.И., Еремеев В.Б.: Сварочные материаль стран-членов СЭВ (Welding materials of 
the CMEA member countries), Справочник (Reference book), K. Moskva, 1979.

[19] Сорокин В.Г., Волосникова А.В., Вяткин С.А., Гервасьев M.A., at al: Марочник сталей и спла$в о в$ (Dictionary of steels and alloys), М.: Машиностроение, Moskva, 1989.

[20] Рыкалин Н.Н., Пугин А.И.: Тепловые прочессы при сварке плавлением (Thermal processes in fusion welding), М.: Профиздат, Moskva, 1959.

[21]Волченко В.Н., Ямпольский В.М., Винокуров B.A. at al: Теория сварочных проиессов (Theory of welding processes), М.: Высшая школа, Moskva, 1988.

\section{NOMENCLATURE}

I welding current

$U \quad$ electric arc voltage

$\eta \quad$ electric arc efficiency coefficient

$q \quad$ heat input of the electric arc

$v_{w} \quad$ welding speed

$q / v_{w} \quad$ heat input of the welding process

$h \quad$ penetration depth

\section{Acronyms}

ATIG Activating Fluxes for arc welding with Tungsten Inert Gas

AMIG Activating Fluxes for arc welding with Metal Inert Gas

TIG Tungsten Inert Gas

MIG Metal Inert Gas

\section{СПЕЦИФИЧНОСТИ ПРИМЕНЕ \\ АКТИВИРАЈУЋИХ ТОПИТЕЉА ПРИ ЕЛЕКТРОЛУЧНОМ ЗАВАРИВАњУ У ЗАШТИТНОЈ АТМОСФЕРИ}

\section{А.М. Савицки, М.М. Савицки, Д. Бајић}

Без повећања струје заваривања активирајући топитељи при електролучном заваривању нетопљивом електродом (АТИГ) и при заваривању топљивим електродама (АМИГ) омогућавају повећање дубине пенетрације 2-4 пута. Ови поступци се суштински разликују у условима нихове реализације. При АМИГ заваривању потешкоће у реализацији завареног споја су последица утицаја критичне вредности површине металног купатила. Критична вредност њене површине се постиже стујом заваривања од 280-300 А и према експерименталним резултатима њена вредност је 160-190 мм². Постизањем критичне вредности површине губи се позитивни утицај активирајућег топитеља на пенетрациону спосо-бност електричног лука. Оптимални интервал струје заваривања за АМИГ је 200-500 А, што значајно превазилази дозвољени праг. При АТИГ заваривању ефекат критичне површине металног купатила не посматра се јер то захтева струју заваривања која превазилази интервал оптималне вредности (макс. 250 А) што је условљено постојаношћу нетопљиве електроде. Повећањем струје заваривања преко 250-300 А, радни крај електроде се брзо троши и стабилност процеса заваривања се нарушава. 